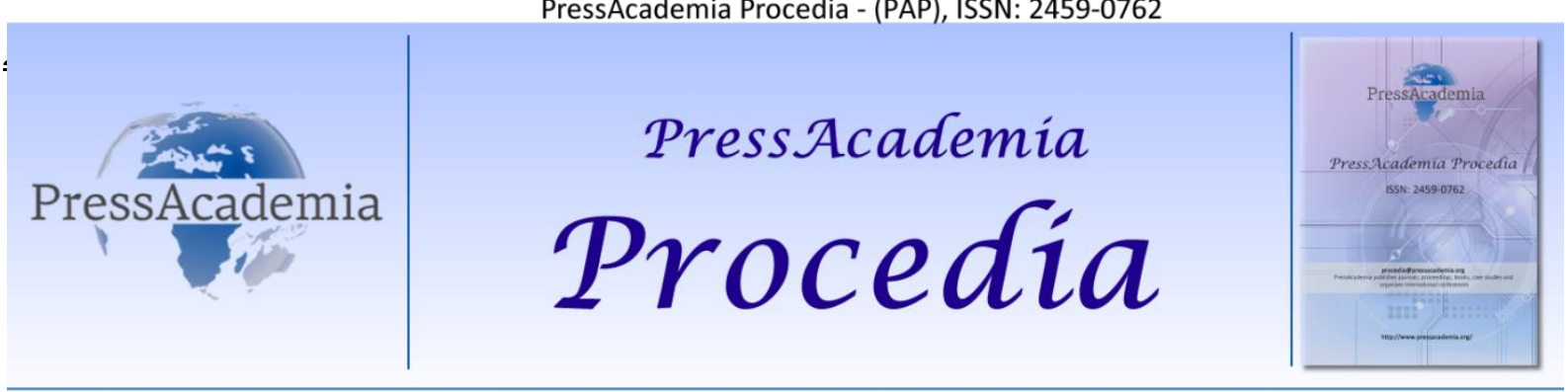

2nd World Conference on Technology, Innovation and Entrepreneurship

May 12-14, 2017, Istanbul, Turkey. Edited by Sefer Şener

\title{
A STUDY ON FINANCIAL ASPECT OF TRADITIONAL FOOD SHOPPING VIA SOCIAL MEDIA
}

\author{
DOI: 10,17261/Pressacademia.2017.524 \\ PAP-WCTIE-V.4-2017(16)-p.105-113 \\ Mustafa Yurttadur ${ }^{1}$, Derya Sari ${ }^{2}$ \\ ${ }^{1}$ Gelisim University, Istanbul, Turkey. myurttadur@gelisim.edu.tr \\ ${ }^{2}$ Gelisim University, Istanbul,Turkey. dsari06@hotmail.com
}

\begin{abstract}
In recent years the efforts of raising awareness of balanced and healthy nutrition in all over the world and in our country have made a successful impact on public. With this awareness and the need to live a longer and healthier life people tend to consume trusting, natural, additive free, healthy, and traditional food.However living conditions make it impossible for people to make traditional foods themselves therefore people are inclined to buy them. Nowadays, traditional food shopping via social media is gradually increasing. In order to meet the demand of traditional food, satisfy the need of consumers and turn this situation into an opportunity numerous micro entrepreneurs use social media (Facebook and Instagram).This research aims to study the importance of social media shopping of traditional foods and the importance of financial aspect of the said shopping. In order to realize this aim, contents were completed and the relationship between literature and contents was promoted with primary work. With conceptual framework, hypothesis of the research has begun to develop. The questionnaire in accordance with this aim provided a research that is primarily about the financial contribution of buying traditional foods via social media to consumers and to the company. The results obtained were evaluated with statistical analysis and tested with hypotheses. According to the analyses, it is found that traditional food shopping via social media provides high financial gain to consumers and companies. It is also ascertained that if the selling rates of the traditional food producers who do marketing via social media increase, their marketing costs decrease and therefore financial profits increase significantly.
\end{abstract}

Keywords: Financial aspect, financial management, financial profitability, traditional food JEL Codes: G10, G23

\section{INTRODUCTION}

The increment in health expenses and the labor loss in working life brought by the nutrition-based problems created an extensive scientific research and a discussion platform by attracting attentions on this subject in recent years. It is discussed in this platform about which food stuff are more healthy, at what ages it should be consumed in what amounts, otherwise which health problems can be faced with. Herein the obesity and the diseases based on obesity in almost every age groups are the major public health problems (Arlı et al., 2006). It could be said that the efforts to raise the awareness of people about healthy life and nourishment in our country and the world achieved to create awareness.

People go into the effort of researching the alternatives of living a more healthy and long life through the internet. In our country and the world, it is known that people notice when they investigate the safety, natural, additive-free and healthy goods that the traditional products can satisfy their needs, and share they this with each other via the social media. Seen that this sharing gradually starts to reach a commercial sector.

\subsection{Definition of Traditional Foods}

The traditional foods are the values consumed for many years in a region, create a part of the kitchen inheritance of a society and the best-fit nourishment style for the biology and physiologies of the people of that community within the centuries. Much as the traditional foods are called as ethnic and regional featured products and tried to based upon the basis of geographical area and region, there is not a standard definition accepted by everyone. They definitively differ from similar foods due to both traditional raw material used in production and traditional methods used in production and processing (Altuntaş and Gülçubuk, 2014). 


\section{PURCHASING TRADITIONAL FOOD VIA SOCIAL MEDIA}

The communication gathered speed by the developing technology in today increased the awareness and sensitiveness of people about environment and health. As a result of these developments and increasing consumer awareness, the consumer preferences significantly shifted from packed take-home foods to the traditional products. Seen in recent years that the interest in traditional food in our country and the world seems to be increasing.

Traditional food products are mostly produced in the home environment or small family businesses based on the limited production amount and marketed in the same regions. Many entrepreneurs in our country are in this business and sell these goods throughout social media. The added value created by the traditional products produced in home environments or small family businesses has reached an ever growing dimension in our country includes pretty much product range. Putting these related products on country and the world markets can significantly contribute to developing that region and its economy as well.

\subsection{The Financial Scale of Purchasing Traditional Foods via Social Media}

At present, the traditional food products emerge as an economic value at the end of the production process and economic activity (Altuntaş and Gülçubuk, 2014). Developing the social media and it's spreading use with globalization caused to increase the competition. We see that the consumers who are aware of the competition in the market of traditional food products started to make more complex requests and enhance their awareness for the price and quality. Under these circumstances, the consumers also consider the commercial scale to return the profit when they buy on social media.

\subsection{The Financial Scale of Selling Traditional Foods via Social Media}

The financial scale involves the long termed goals of the company, profitability, and growth. The need for knowledge increases by the rapidly changing conditions of competition, technological improvements and new methods and techniques applied in enterprises. The companies have to consider and analyze the financial and non-financial factors about the global business world and activity areas beside internal data to return a profit and maintain their presence (Uygur, 2009). The companies embarked on a quest for new methods by noticing the classical methods just measure the financial values but not allow for the analysis of the problem. The balanced success indicator affects the efficient use of source and time by also providing to be evaluated the company thoroughly (Ağca and Tunçer, 2006).

\subsection{The Financial Cost and Profitability of Selling Traditional Foods via Social Media}

The companies need to be involved in activities such as production, financing, and management of the human sources to achieve the goal (Mucuk, 2013). The marketing is placed on the top of the functions which provide the companies succeed. The enterprises that sell the traditional foods via social media also increase their profitability by partially minimizing the marketing cost

\subsection{The Financial Management of Selling Traditional Foods via Social Media}

It needs to be correctly determined the requirements of the company, designed the scorecards consisting of performance criteria within a cause-effect relationship, being the measurements accurate and realist to succeed the management (Güner, 2008).

Much as the financial management as accepted as a different part of the business economy and being provided the means of payment at the start, then the extent of the financial management exceed this classical perspective. Accordingly, the financial management involves being used the reserves effectively and the audit of the success in this field besides being provided these reserves on easy terms.

\subsection{The Effect of Selling Traditional Foods via Social Media on the Growth}

Due to the modificatory conditions, the purpose of accelerating the development and growth consisting of necessary fiscal policies in every country is changed as stopping the price increase, avoiding the black market and abolish the deflation (Şener, 2004).

Since the financial criteria are beneficial to summarize the measurable economic results of the current situation about previous businesses, DSK BALANCED SCORECARD keeps the financial scale as so (Kaplan and Norton, 1999: 33). Because of this, DSK articulates the financial purposes and helps to companies to determine specific financial goals for each period of the course of life of the companies such as growth, maintenance and obtaining results (Ölçer, 2005: 93).

The financial criteria are determined based on the size, sector in which operates and own conditions (Bean and Jarnagin, 2002: 56). These criteria generally focus on the performance indicators like profitability, growth, net income, increase in sales, cash flow and economic added value (Hornsby and Baxendale, 2001: 5). The financial purposes and the criteria of 
companies may differ based on the level of the company on the business life cycle (growth, publicity, maturity, etc.) (Hornsby and Baxendale, 2001: 5). The financial criteria such as sales status and cash flow are essential for a company at publicity level, while other financial criteria like profitability, net income may be more important for the companies at the maturity level.

\subsection{Theoretic Framework and Hypotheses of the Research}

\section{Variables of the Research}

- Dependent Variable: Financial Scale

- Independent Variable: Social Media

- Mediator Variable: The Perception of Purchasing the Traditional Foods via Social Media

The hypotheses developed in this research are proposed as follows

$\mathrm{H}_{1}$ : The gainings of purchasing traditional food via social media is high for the consumer.

$\mathrm{H}_{2}$ : The gainings of purchasing traditional food via social media is high for the company.

$\mathrm{H}_{3}$ : As the sales of traditional food producers increase via social media, marketing costs decrease.

$\mathrm{H}_{4:}$ As the sales of traditional food producers increase via social media, their profitabilities increase.

\section{Figure 1: Theoretic Framework of the Research}

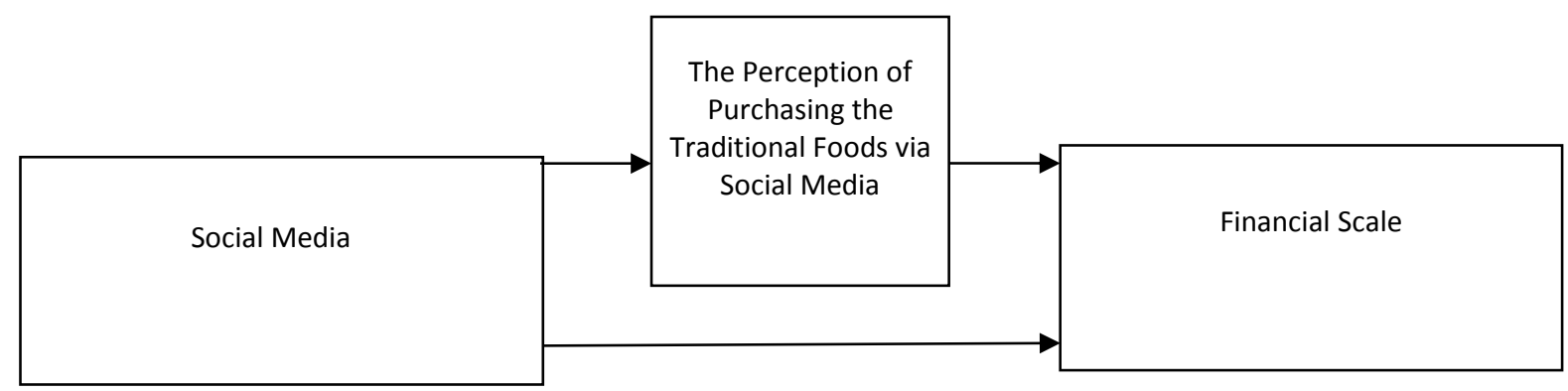

\section{RESEARCH METHODOLOGY}

The survey was prepared by Google Forms on the Google Drive. Totally 1341 of social media users attended in the inquiry. The universe of the research consists of the users of social media. The data obtained in research were collected by using the survey method. It is tried to gather information based on five-point Likert scale besides the open and close ended questions.

\subsection{Purpose of the Research}

The goal of this research is to reveal how important the purchasing traditional food via social media and the commercial scale of this purchasing are.

\subsection{Sampling of the Research}

The questionnaire forms were sent 3128 members of pages of traditional food shopping in Facebook and Instagram when creating the sample of the research. 1341 of them made a comeback (The ratio of the comeback of the surveys is $42,87 \%$ ).

\subsection{Data Collection Method of the Research}

The survey technique is used in this study. The data collected were analyzed by SPSS 22.0 program. The statistical techniques are used in this study such as Cronbach's Alpha (Reliability), Chi-Square Test and frequency distribution. Totally 42 questions were asked, and the answers were evaluated in 5 points Likert scale to measure the variables about purchasing traditional foods via social media and the financial extent of this purchasing. 


\section{ANALYSIS OF THE DATA OF RESEARCH}

The data obtained from the surveys were recorded in the electronic environment and analyzed by transferring to SPSS 22.0 program. Cronbach's Alpha test, Chi-Square test were used in analyses; the frequency, percentage values, and the graphic data were determined as well.

Table 1: Cronbach's Alpha Test

\begin{tabular}{|c|c|}
\hline Cronbach's Alpha & N of Items \\
\hline, 860 & 10 \\
\hline
\end{tabular}

Cronbach's Alpha test determined the reliability of the questions prepared to analyze the financial extent of purchasing traditional food via social media. As is seen in Table 1, the result of $0,860(0.7 \leq a<0.9)$ is accepted as 'good' based on the measurement criterion of Cronbach's Alpha test.

Table 2: Chi-Square Tests- Do you buy traditional food product via social media?* The customers who buy the traditional foods via social media have small expenses.

\begin{tabular}{lccr}
\hline & Value & df & Asymp. Sig. (2-sided) \\
\hline Pearson Chi-Square & $1012,514(\mathrm{a})$ & 3 &, 000 \\
Likelihood Ratio & 1146,563 & 3 &, 000 \\
Linear-by-Linear & 789,577 & 1 &, 000 \\
Association & 1341 & & \\
\hline N of Valid Cases & & & \\
\hline
\end{tabular}

a 2 cells $(25,0 \%)$ have expected count less than 5 . The minimum expected count is, 82 .

According to Chi-Square analysis in Table 2, determined that the significance value is less than $0,000<0,005$ when being analyzed if there is a relation between the variables or not in the distribution of propositions called 'Do you buy traditional food product via social media? and 'The customers who buy the traditional foods via social media have small expenses.' In this case, the hypothesis ' $\mathrm{H} 1$ : The gainings of purchasing traditional food via social media is high for the consumer' is accepted.

Table 3: Do you buy traditional food product via social media?

\begin{tabular}{cccccc}
\hline & & Frequency & Percent & Valid Percent & Cumulative Percent \\
\hline Valid & Evet & 974 & 72,6 & 72,6 & 72,6 \\
& Hayır & 367 & 27,4 & 27,4 & 100,0 \\
\hline & Total & 1341 & 100,0 & 100,0 & \\
\hline
\end{tabular}

It can be seen when Table 3 is analyzed that the participants of survey buy traditional food products by using the means social media. The ratio of buyers is $72,6 \%$ while the rate of people who say 'no' is $27,4 \%$.

Graphic 1: Do you buy traditional food product via the means of social media?
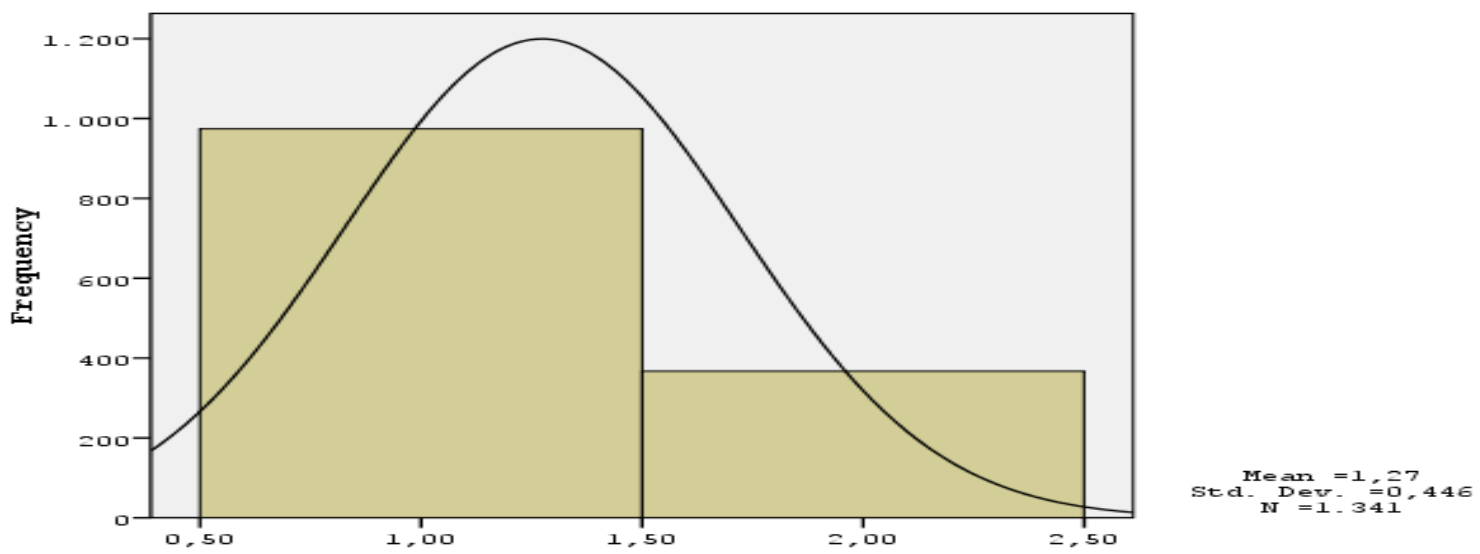
Table 4: The customers who buy the traditional foods via social media have small expenses.

\begin{tabular}{llcccc}
\hline & Frequency & Percent & Valid Percent & Cumulative Percent \\
\hline \multirow{2}{*}{ Valid } & Absolutely Agree & 583 & 43,5 & 43,5 & 43,5 \\
& Agree & 311 & 23,2 & 23,2 & 66,7 \\
& I'm on the fence & 444 & 33,1 & 33,1 & 99,8 \\
& Disagree & 3 &, 2 &, 2 & 100,0 \\
\hline & Total & 1341 & 100,0 & 100,0 &
\end{tabular}

According to Table 4, the ratio of participants who think that the customers who buy the traditional foods via social media have small expenses is $66,7 \%$. The ratio of irresolute is $33,1 \%$, and people who disagree is $0,2 \%$.

Graphic 2: The customers who buy the traditional foods via social media have small expenses.

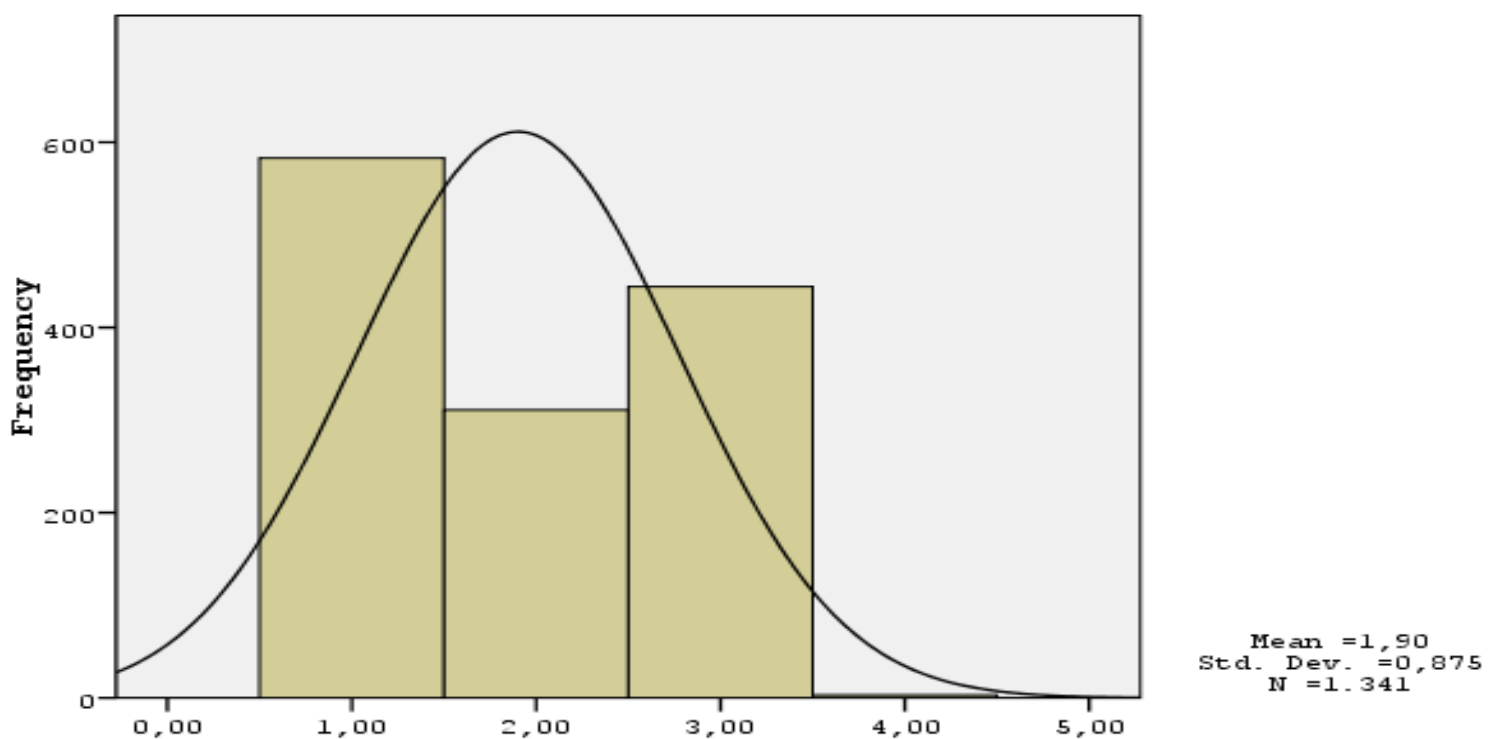

Table 5: Chi-Square Tests- Do you buy traditional food product via the means of social media?* Selling a product via social media is low-cost in comparison with selling the same product at retail or wholesale.

\begin{tabular}{lccc}
\hline & Value & df & Asymp. Sig. (2-sided) \\
\hline Pearson Chi-Square & $1007,665(a)$ & 3 &, 000 \\
Likelihood Ratio & 1134,998 & 3 &, 000 \\
Linear-by-Linear & 783,255 & 1 &, 000 \\
Association & 1341 & & \\
\hline N of Valid Cases & \multirow{2}{*}{} & & \\
\hline
\end{tabular}

a 2 cells $(25,0 \%)$ have expected count less than 5 . The minimum expected count is, 82 .

According to Chi-Square analysis in Table 5, determined that the significance value is less than $0,000<0,005$ when being analyzed if there is a connection between the variables or not in the distribution of propositions called 'Do you buy traditional food product via the means of social media?' and 'Selling a product via social media is low-cost in comparison with selling the same product at retail or wholesale in a place.' In this case, the hypothesis ' $\mathrm{H} 2$ : The gainings of purchasing traditional food via social media is high for the company' is accepted. 
Table 6: Selling a product via social media is low-cost in comparison with selling the same product at retail or wholesale in a place.

\begin{tabular}{llcccc}
\hline & Frequency & Percent & Valid Percent & Cumulative Percent \\
\hline \multirow{2}{*}{ Valid } & Absolutely Agree & 582 & 43,4 & 43,4 & 43,4 \\
& Agree & 313 & 23,3 & 23,3 & 66,7 \\
& I'm on the fence & 443 & 33,0 & 33,0 & 99,8 \\
& Disagree & 3 &, 2 &, 2 & 100,0 \\
\hline Total & 1341 & 100,0 & 100,0 & \\
\hline
\end{tabular}

According to Table 6, 66,7\% of participants are agree with the question called 'Selling a product via social media is low-cost in comparison with selling the same product at retail or wholesale in a place.' Rest of the percentage composed of irresolute $(33,0 \%)$.

Graphic 3: Selling a product via social media is low-cost in comparison with selling the same product at retail or wholesale in a place

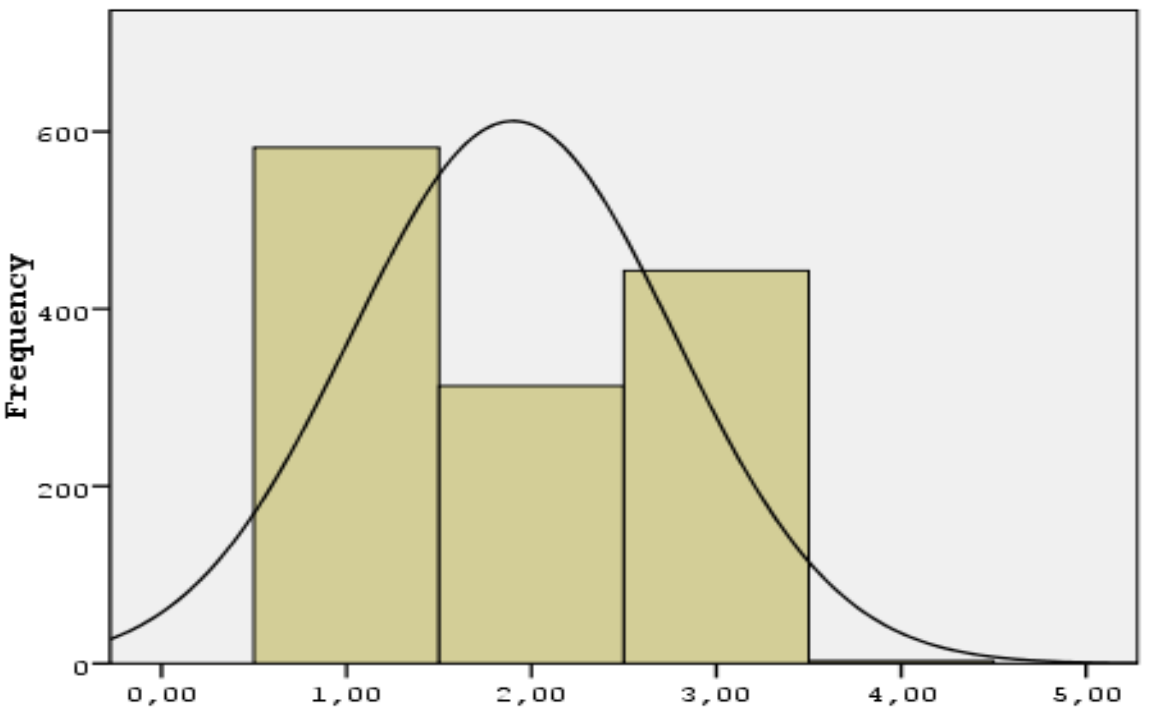

Table 7: Do you buy traditional food product via the means of social media you use?* As the sales of companies increase via the internet, the costs of marketing get the decrease.

\begin{tabular}{lccr}
\hline & Value & df & Asymp. Sig. (2-sided) \\
\hline Pearson Chi-Square & $781,164(\mathrm{a})$ & 3 &, 000 \\
Likelihood Ratio & 910,639 & 3 &, 000 \\
Linear-by-Linear & 673,335 & 1 &, 000 \\
Association & 1341 & & \\
\hline N of Valid Cases & & & \\
\hline
\end{tabular}

a 2 cells $(25,0 \%)$ have expected count less than 5 . The minimum expected count is, 55 .

According to Chi-Square analysis in Table 7, determined that the significance value is less than $0,000<0,005$ when being analyzed if there is a relationship between the variables or not in the distribution of propositions called 'Do you buy traditional food product via the means of social media you use? and 'As the sales of companies increase via the internet, the costs of marketing get the decrease.' In this case, the hypothesis ' $\mathrm{H} 3$ : As the sales of traditional food producers increase via social media, marketing costs decrease' is accepted. 
Table 8: As the sales of companies increase via the internet, the costs of marketing get the decrease.

\begin{tabular}{llcccc}
\hline & Frequency & Percent & Valid Percent & Cumulative Percent \\
\hline \multirow{2}{*}{ Valid } & Absolutely Agree & 629 & 46,9 & 46,9 & 46,9 \\
& Agree & 189 & 14,1 & 14,1 & 61,0 \\
& 521 & 38,9 & 38,9 & 99,9 \\
& I'm on the fence & 2 &, 1 &, 1 & 100,0 \\
\hline & Disagree & 1341 & 100,0 & 100,0 & \\
\hline
\end{tabular}

With respect to Table 8 , totally $818(61 \%)$ of attendees replied in the affirmative for the question called 'As the sales of companies increase via the internet, the costs of marketing get decrease.' The ratio of irresolute is $38,9 \%$.

Graphic 4: As the sales of companies increase via the internet, the costs of marketing get a decrease.
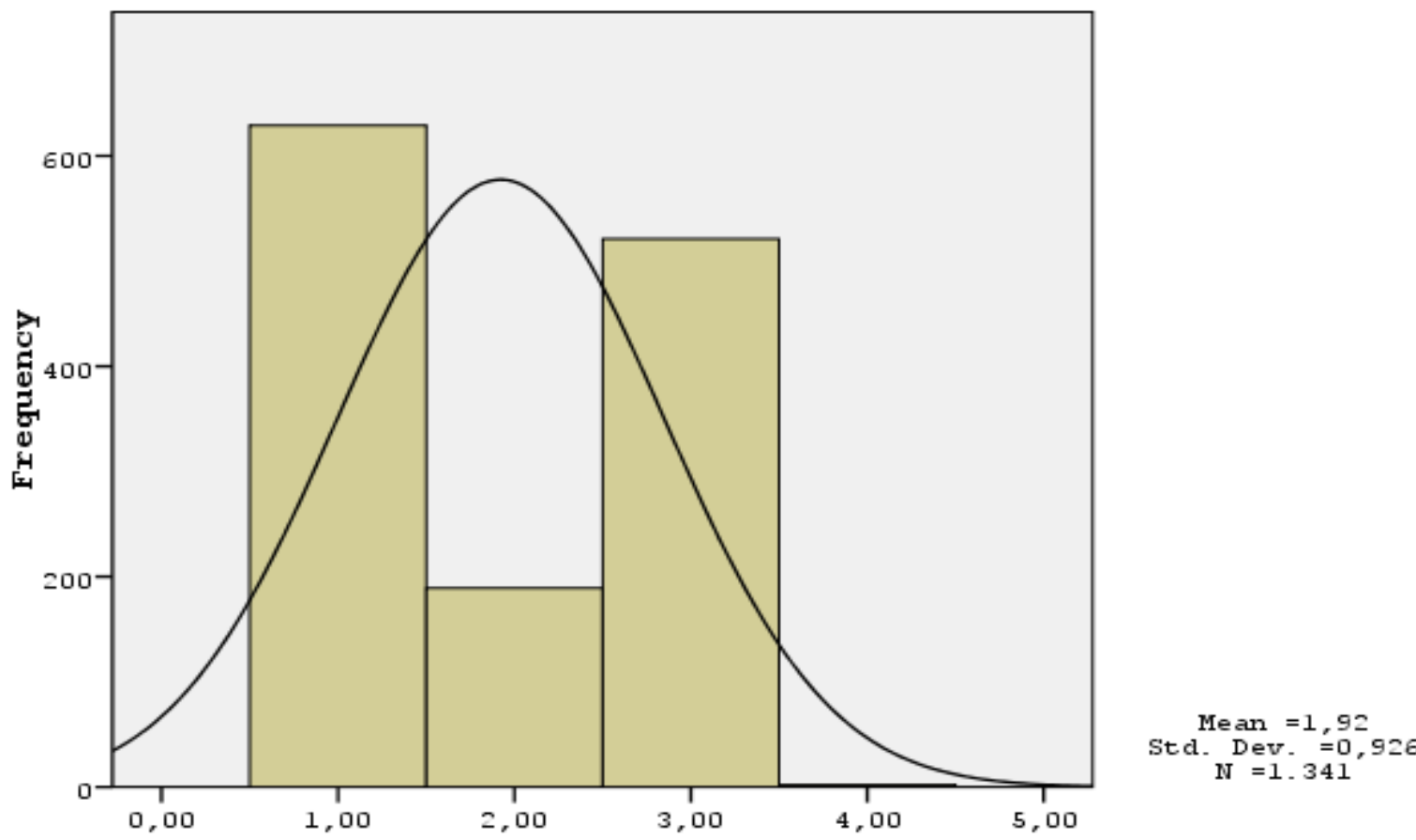

Table 9: Chi-Square Tests- Do you buy traditional food product via the means of social media you use?* As the sales of companies increase via the internet, their profitability gets increase more and more.

\begin{tabular}{lccc}
\hline & Value & df & Asymp. Sig. (2-sided) \\
\hline Pearson Chi-Square & $1012,514(\mathrm{a})$ & 3 &, 000 \\
Likelihood Ratio & 1146,570 & 3 &, 000 \\
Linear-by-Linear & 788,660 & 1 &, 000 \\
Association & 1341 & & \\
\hline N of Valid Cases & & & \\
\hline
\end{tabular}

a 2 cells $(25,0 \%)$ have expected count less than 5 . The minimum expected count is, 82 .

According to Chi-Square analysis in Table 9, Determined that the significance value is less than $0,000<0,005$ when being analyzed if there is a relation between the variables or not in the distribution of propositions called 'Do you buy traditional food product via the means of social media you use? and 'As the sales of companies increase via the internet, their profitability gets raise more and more.' In this case, the hypothesis ' $\mathrm{H} 4$ : As the sales of traditional food producers increase via social media, their profitabilities increase' is accepted. 
Table 10: As the sales of traditional food producers increase via social media, their profitabilities increase.

\begin{tabular}{llcccc}
\hline & Frequency & Percent & Valid Percent & Cumulative Percent \\
\hline \multirow{2}{*}{ Valid } & Absolutely Agree & 581 & 43,3 & 43,3 & 43,3 \\
& Agree & 313 & 23,3 & 23,3 & 66,7 \\
& I'm on the fence & 444 & 33,1 & 33,1 & 99,8 \\
& Disagree & 3 &, 2 &, 2 & 100,0 \\
\hline Total & 1341 & 100,0 & 100,0 & \\
\hline
\end{tabular}

According to Table 10, $894(66,6 \%)$ of participants mentioned as 'As the sales of traditional food producers increase via social media, their profitabilities increase.' The ratio of irresolute is $33,1 \%$.

\section{Graphic 5: As the sales of traditional food producers increase via social media, their profitabilities increase more and more.}

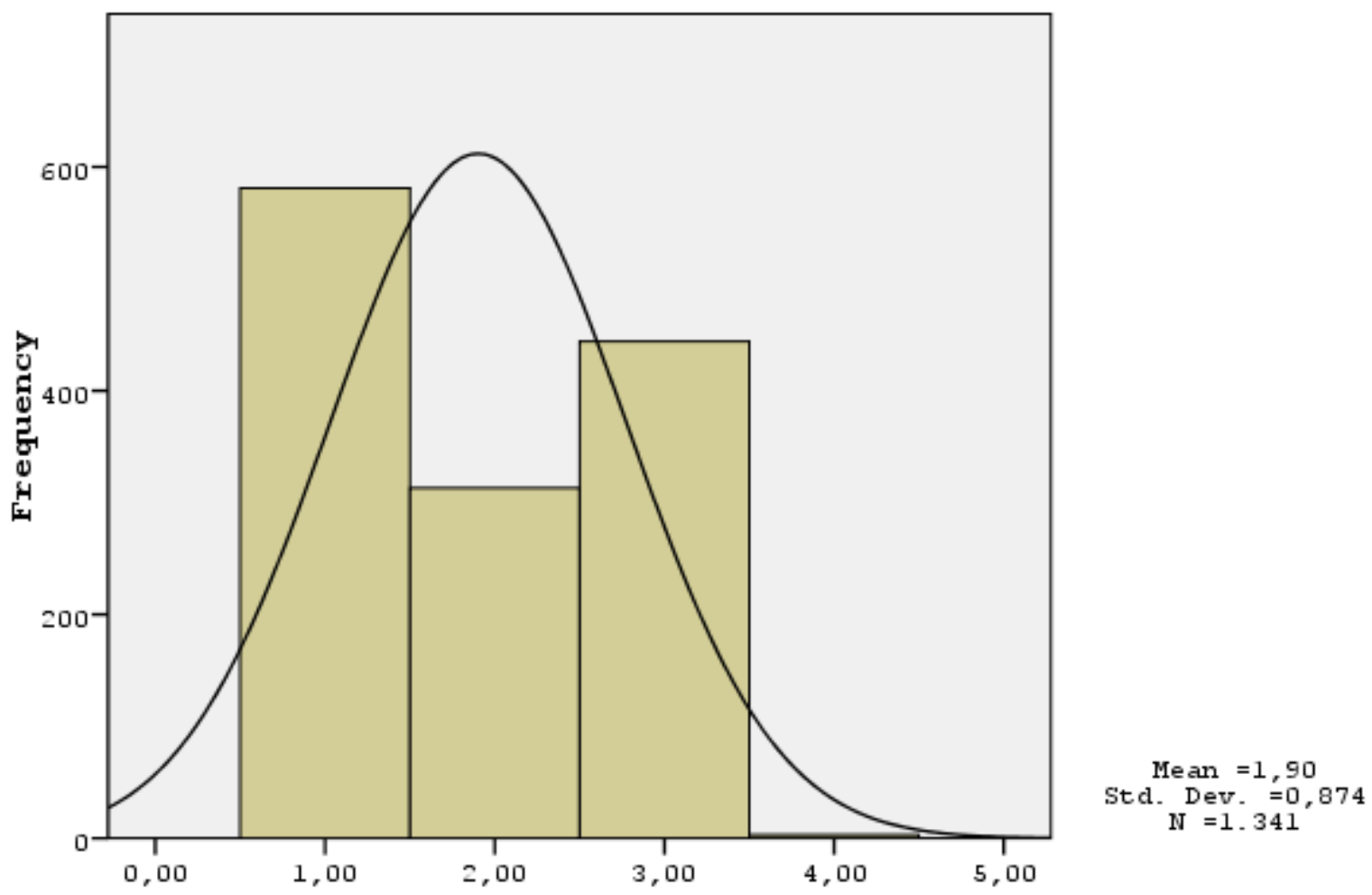

\section{CONCLUSION}

It is seen when being evaluated the commercial scale of purchasing traditional foods via the internet by the users of social media in terms of the consumers that the return of traditional food products is financially high. And about the companies, the profitability is increased due to the decrease in costs of marketing, so the profitability mounted up. The answers of participants were tested and the hypotheses proposed were accepted either.A vast majority of the users of social media attended to the survey consists of women, and the greatest common factor for them to choose the traditional food products is that they think about these products are made from healthy and organic goods.

Determined by the analyses actualized that the married attendees care more than bachelor ones about being traditional food products hormone-free, additive-free and homemade. It is observed when the opinions of participants are analyzed based on the ages that, the attendees who are between the ages of $25-29$ care more than the age group between 40 and 44 about being the traditional products hormone-free, additive-free and not genetically modified. For the participants in an age group of 20-24, being traditional products additive-free is less significant in comparison with the ages between 40 and 44. It can be easily said in other words that the characteristics of the traditional products are more important for the attendees in ages between 25-29 than 40-44. It is seen within the general scope of the survey that the participants who buy traditional food product via the internet are high trained and have high income also. These users frequently use the 
social media channels because of being these channels productive in terms of time management. The changes happen in features of shopping by the developed technology. There is determined when all these results are evaluated concerning seller and consumer that the financial return of selling traditional food products via social media is at high levels.

\section{LIMITEDNESS OF THE RESEARCH}

Our research is limited with the perceptions of members of the groups of traditional food shopping in Facebook and Instagram about the financial dimension of purchasing these products via social media. So, it cannot be generalized due to this research does not involve all of the social media users. This study also embodies the limitedness belong to people. The information of people about using of social media reflects their perception and personal characteristics. That's why the answers in this survey do not represent the general.

\section{REFERENCES}

Ağca, V., Tunçer, E. 2006, "Multidimensional performance assessment models and an example of balanced scorecard". Afyon Kocatepe University. Journal of Faculty of Economics and Administrative Sciences 8 (1), pp.173-193.

Altuntaş, A., Gülçubuk, B. 2014, "The Traditional Foods as a Spreading Mean in Local Development and Spreadability of Traditional Food Legislation”, İstanbul, Gaziosmanpaşa University Journal of Agricultural Faculty, 31 (3), pp.73-81.

Arlı, M. et al., 2006, “Nourishment of mother and child”, Ankara, Pegem A Publishing House, p. 101.

Bean, L. Ve Jarnagın, B.D. 2002, “New Cost Priorities: Using a Balanced Scorecard Approach in Financial Reports”, The Journal of Corporate Accounting, March-April, pp 55-62.

Güner, M. F. 2008, "Balanced Scorecard as a Strategical Management Model”, Ankara, Gazi University Journal of Faculty of Economics and Administrative Sciences 10,1, pp. 247 - 265

Hornsby, D.D. Ve Baxendale, S. 2001, “Building a Balanced Scorecard for Entrepreneurs", Journal of Cost Management, NovemberDecember, pp. 4-9.

Kaplan, R.S. and Norton, D.P. 1999, “Balanced Scorecard, Transforming the Company Strategy into the”, İstanbul, Sistem Publishing, p.33.

Mucuk, İ. 2013, “Basic Marketing Knowledge”, İstanbul, Türkmen Bookstore, p. 1.

Ölçer, F. 2005, “(Balanced Scorecard) Designing and Applying the Balanced Strategical Performance Measuring and Management System' Ankara, Journal of Public Administration, Volume:38, No:2 , pp. 89-134.

Şener, S. 2004, "SeekingSeekings of Agriculture Policy in Turkey in the Years of Second World War", Journal of Social Sciences Institute (7), 1, pp. 73-92.

Uygur, A. 2009, "Balanced Success Indicator as a Multidimensional Performance Assessments Model", İstanbul, Journal of Doğuş University 10 (1), pp. $148-159$. 